\title{
Vaccine Therapy for the Prostate Cancer
}

\section{Prostat Kanserinde Aşı Tedavileri}

\author{
Mehmet Giray Sönmez, Cengiz Kara \\ Medical Park Ankara Hospital, Clinic of Urology, Ankara, Turkey
}

\begin{abstract}
The aim of using vaccine in the treatment of prostate cancer (Pca) is to activate immune response against malignant cells by overcoming the tolerance triggered by the tumor. Vaccine therapies are effective by using the immune response against cancer. The first oncological vaccine therapy ever published in the literature belongs to Coley dating back to 1893. In that study, it has been demonstrated that inoperable soft tissue sarcomas were regressed by stimulating non-specific immune response with streptococcal toxins. Not every type of cancer is suitable for vaccine therapy. For a vaccine therapy to be implemented, the cancer should have a slow progression, it should be immunogenic, and contain tissue-specific proteins. For that reason, studies regarding urological cancers, most of which are phase $1 / 2$ and phase 3 , are focused on the kidneys and the prostate. Although vaccine therapy in oncological diseases dates back to old times, studies have only been intensified recently. In this compilation, we will discuss vaccine therapies that are being used in prostate cancer, which urologists are not so familiar with, in the light of the up-to-date literature.
\end{abstract}

Key Words

Prostate cancer, vaccine therapy, immunotherapy

\section{ÖZET}

Prostat kanserinin (Pca) tedavisinde aşı kullanımının amacı tümörün tetiklediği toleransı yenerek malign hücrelere karşı oluşan immün cevabı aktive etmektir. Aşı tedavileri kansere karşı immün cevabı kullanarak etki gösterir. Literatür de yayınlanan ilk onkolojik aşı tedavisi 1893 yılında Coley tarafından yayınlanmıştır. Bu çalışma da inoperable yumuşak doku sarkomlarının streptokokal toksinler ile non-spesifik immün cevap oluşturularak regrese olduğu gösterilmiştir. Her kanser çeşitinde aşı tedavileri uygun değildir. Aşı tedavisinin uygulanabilmesi için; kanserin yavaş ilerlemesi, immmünojenik olması, dokuya özgü proteinler içermesi gereklidir. Bu nedenle ürolojik kanserler içinde çoğu faz $1 / 2$ ve faz 3 olmak üzere çalışmalar böbrek ve prostat üzerine yoğunlaşmıştır. Onkolojik hastalıklarda aşı tedavileri eskiye dayanmasına rağmen özellikle çalışmalar son dönem de yoğunlaşmıştır. Bizde bu derlemede üroloji hekimlerinin çok aşina olmadığı, güncel literatür eşliğinde prostat kanserinde kullanılan aşı tedavilerinden bahsedeceğiz.

Anahtar Kelimeler

Prostat kanseri, aşı tedavisi, immünoterapi

\section{How is Cancer Immune Response Formed?}

When the cancer cells first start to multiply, macrophages phagocyte the cancer cells while other cancer cells occupy the nearby tissues and cells. Macrophages digest the cancer cells and demonstrate antigenic parts of cancer cells on the surface. After that by connecting to the microphages (dendritic cells), T helper cells recognize the presented antigens and this connection causes the release of many cytokines from both cells. Thus, antigen presentation as an immune response to cancer takes place. The released cytokines induce the formation of more cytokines and antibodies by inducing especially the IL-2, $\mathrm{T}$ helper, cytotoxic T and B cells. Induced cytotoxic T cells headed towards the cancer cells which are carrying the same antigen start to form holes on these. Thus, a cytotoxic effect towards cancer is demonstrated. Finally, antibodies released from B cells connect to free floating cancer cells, and thus, a target to destroy is shown to the microphages, and complement system is activated. When the cancer cells are under control, B and T cells are passivated by suppressor T cells. Stored T and B Cells stay ready in order to provide quick response in case antigens for cancer cells are observed $(1,2)$.

\section{Vaccine Platforms}

Used vaccine treatments can be divided into main titles as the following (3);

- Tumour cells (autologous and allogenic)

- Dendritic cell

- DNA

- Viral vector 
- Protein/peptide

- Immune regulators

\section{Immunotherapy in Prostate Cancer}

\section{GVAX: Tumour Cell Vaccine (Intradermal)}

Allogenic prostate cancer (PCa) cells are used as immunotherapy vectors in this tumour vaccine. It is formed by two PCa cell series called PC3 and LNCaP.

LNCaP: Cancer cells with lymph node metastasis secrete many prostate surface antigens including prostate-specific antigen/ prostate-specific membrane antigen (PSA/PSMA).

PC-3: These are androgen-resistant cells obtained from bone metastasis (4).

Normally, cancer cells are not immunogenic. The cells are genetically modified by applying radiation and adenoviral transfer to PC-3 and LNCaP cell series. These cells take effect inhibiting the division of cancer cells with cytokines secreted by becoming immune active $(5,6)$.

Simons et al. (phase 2 study) followed up 24 patients with castrationresistant prostate cancer (CRPC) for two years giving high-dose and love-dose GVAX treatment and found that the high dose group survival was 70\% compared to the 41\% survival rate in low-dose survival group (7). Average survival was 26.2 months in a phase 2 study on 55 metastatic CRPC patients, 23.1 months in low-dose group in phase 2 study on 80 metastatic CRPC patients and 35 months in high-dose group and, it was detected that GVAX treatment was safe and tolerated. Autoimmune toxicity was not present in the patients and it was observed that high-dose treatment was more effective on survival. The most common treatment-based side effects were fatigue, myalgia, arthralgia, and infection-site reaction $(8,9)$. After that, phase 3 studies for GVAX were started. In a phase 3 VITAL 1 study, 626 asymptomatic CRPC patients not having chemotherapy but randomized docetaxel/prednisone branches were evaluated for survival period. However, it was observed that 279 patients died during follow-up. As the recovery rate in survival analysis, which was the main target of the study, was lower than 30\%, the study was stopped (10).

In a phase 3 VITAL 2 study, as higher death rate (67\% and 47\%) was observed in the group of 600 symptomatic CPRC patients with randomized docetaxel/prednisone branches, this study was also stopped (11).

\section{Sipuleucel-T (Provenge): Dendritic Cell Vaccine}

Autologous dendritic cells are used as vaccine. The enzyme located in the prostate cell membrane is dendritic cell-based vaccine with cytotoxic effect on prastatic acid phosphatase (PAP).

It is based on taking mononuclear cells (monocyte and lymphocyte) from the peripherical blood of patients with plasmapheresisleukopheresis and incubation with prostatic acid phosphatase (PAP) which is the target antigen and granulocyte macrophage colony stimulating factor (GM-CSF) (12). Cells presenting antigen sensitivized by modified PAP have an anti-tumor effect against PAP producing PCa cells $(13,14)$.

Infusion is made three days after leukapheresis. Slow infusion in an hour and 3 leukapheresis sessions at most in a month should be applied. As the treatment is immunogenic, pre-treatment antipyretic and antihistaminic premedication is recommended. Common side effects include: feeling cold (54.1\%), weakness (39.1\%), fever (29.3\%), nausea (28.1\%), and back ache $(13,14)$.

In a phase 3 study, 127 patients with metastatic asymptomatic PCa were divided into sipuleucel-T and placebo branches and, at the end, it was observed that there was no difference between the groups when disease and pain development was considered, but an important advantage was observed in sipuleucel-T branch in 3-year survival (15).

In a similar phase 2 study, 98 patients with metastatic PCa were randomized in sipuleucel-T and placebo branches. In this study, no advantage was found in 3-year survival in sipuleucel-T branch (16). In post-hoc analysis of these two studies (225 patients), average survival period was reported to be 23.2 months in sipuleucel-T branch while it was 18.9 months in placebo branch (17).

In FDA controlled phase 3 IMPACT study in which 75 centres were included, 512 asymptomatic or minimal symptomatic metastasic CRPC patients were separated into placebo (171 patient) and Sipuleucel-T (341 patients) branches and patients were followed for 34.1 months in average. Decrease in relative death risk was determined as $22 \%$ in medicine branch. Average survival was observed as 25.8 months in medicine branch and 21.7 months in placebo branch. 4.1 months of survival advantage was detected in medicine branch. Although the 3 year total survival was 38\% more than placebo, it was reported that the medicine had no effect on the time passing up to progression. After this study Sipuleucel-T FDA consent was taken $(16,18)$.

Disadvantages of Sipuleucel-T treatment: They can be listed as having no effect on the time passing up to progression, the possibility of late regression in secondary PSA to immune response time, inability to effectively follow the patients with PSA and progression response for these reasons and the cost of 3 leukopheresis sessions being 93000 USD and not being docataxel compared study.

Advantages of Sipuleucel-T treatment: They were observed as general survival advantage, good tolerability, short treatment duration (30 days), not prohibiting treatment which may be applied after as in chemotherapy, mild side effect profile (4).

In 2015 National Institute for Health and Care Excellence (NICE) stated that asymptomatic or minimal symptomatic CRPC usage instead of Sipuleucel-T's usage in metastasic patients is more appropriate (19).

\section{Prostvac VF-Tricom: Viral Vector Vaccine}

The aim of this vaccine is activating a stronger immune system activation by synthesizing high amount of prostate cancer cell or antigen by viral vectors. The vaccine called Prostvac was formed by synthesizing from the combination of flower viruses and recombinant PSA with heterologous prime-boost strategy (16). A more immugenic vaccine called TRICOM was formed by using viral DNA plasmids with the combination of three stimulator proteins CD80, intracellular adhesion molecule-3 (IAM3) and leukocyte function antigen-3 (LFA3) (20).

No toxicity was observed in four weeks in the phase 1 study made and 8 week PSA stabilization was observed in $40 \%$ of the cases (21). In phase 2 study, 82 (42/40) metastasic CRPC patients were randomized into placebo and prostvac branches and survival was observed as 25.1 months in survival medicine branch and 16.6 months in placebo 
branch (22). In a similar phase 2 study, survival was detected as 26.6 months in prostvac branch and 17.4 months in control branch (23). Studies were continued when positive effects on survival were observed. In different phase 2 studies Prostvac was reported as being more effective in less aggressive and early stage cancer (24), a significant decrease was determined in tumour growth speed in three months in 50 non-metastasic prostate cancer patients (25). In Phase 1 study including ProstVac VF+ ipilimumab (increases T lymphocyte regulation surrounding the tumour) treatment, it was reported that the treatment was safe, tolerable and the average survival was more than the prostvac monotherapy (26). The results of Phase 3 studies in which Prostvac+GM-CSF combination is used and Prostvac and docataxel treatment is compared are not determined yet.

A two-stage treatment was applied to Pca patients without apparent metastasis in the current phase 2 study made and Prostvax+GM-CSF treatment in the first stage and androgen ablation treatment in the second stage was given. While pre-treatment median PSA velocity was $0.13 \log (P S A)$ per month and PSA doubling time was 5.3 months, PSA velocity was measured $0.09 \log$ (PSA) per month and PSA doubling time was measured 7.7 months. Complete response was reported in 20 of 27 patients after two staged treatment. As the number of patients is limited in this study and there is no control group, it is limited to evaluate the success of the treatment (27).

\section{DNA and RNA Based Vaccines}

\section{DNA-Prastatic Acid Phosphatase and DNA-Prostate Specific Antigen: DNA-Based Vaccines}

They contain genetic structure coded specifically for prostate specific proteins. Plasmid DNA vaccine for PAP is called DNA-PAP (pTVG-HP) PAP) and PSA producing DNA plasmid vaccine is called DNA-PSA (pVAX/ PSA) vaccine.

In the phase $1 / 2$ a study made, human PAP coding plasmic vaccine (DNA-PAP) + GM-CSF was given to 22 non-metastasic PCA patients with biochemical progression and PSA doubling time prolongation and increase in PAP specific T lymphocyte response was determined (28).

In phase 1 study which was made by giving DNA-PSA + GMCSF+IL-2 to nine CRPC patients, PSA specific significantly increased T cell response and PSA doubling period prolongation in two out of five patients given high dose were reported (29). In spite of these results, use of DNA based vaccines are limited with potential low efficiency.

\section{CV9103 and CV9104: mRNA vaccine (RNActive ${ }^{\circledR}$ )}

It is a nucleotide based vaccine. Sufficient antigen expression formation, autologous immune stimulation and flexibility in production and application are positive characteristics of these vaccines. In phase 1/2 studies, there are studies showing that CV9013 is well tolerated, makes immune-activation and CV9104 has positive effect as neoadjuvant in high risk prostate cancer and CPRC patient (30).

\section{AdV-tk: Cytotoxic Immunotherapy with Gene Agent}

It includes the inner tumour application of adenovirus coded with thymidine kinase which is a herpes simplex virus enzyme. Tumour cells with transduction become over sensitive with valaciclovir (VCV) and ganciclovir (GCV). These medicines especially effect the neighbour cells which reproduce quickly afterwards (local bystander effect). They immunologically attack systematic metastasises and protect against tumour recurrence (systemic bystander effect) (31).

In Phase 1-2 study made with 23 local advanced Pca patients, safety and treating potential of AdV-tk was tested before the prostatectomy and AdV-tk was injected intraprostatically and prostatectomy was made 2-4 weeks after the 2 week GCV treatment. As a result, significant $\mathrm{CD} 8+\mathrm{T}$ lymphocyte increase in blood and resected prostate tissue was detected and no change in $\mathrm{CD} 4+\mathrm{T}$ lymphocyte, natural killer level and no significant recovery in biochemical PSA recurrence and prognosis was observed. Adv-tk-based and chemotherapy combination therapies have not been completely researched clinically (32).

In Phase I/II study made AdV-tk and combined radiotherapy (RT) was applied to patients with prostate cancer, the patients were separated in three categories with 4 patients in each as 29 patients with low risk (stage T1-T2a, Gleason score $<7$ ), 26 patients with high risk (stage T2b-T3, Gleason score >6) and 44 patients with D1 disease. Average follow-up period in the study was more than 13 months. It was observed that PSA levels were under control in all low risk and high risk patients. But in three of D1 patients, biochemical failure was detected (33). Phase 3 study "ProstAtak ${ }^{\text {TM" }}$ including medium-high risk localized prostate cancer patients with placebo controlled, AdVtk+radiotherapy combinations application still goes on.

Main studies with vaccine treatment in prostate cancer and continuing studies are summarized in Table 1 and Table 2.

\section{Immune Regulators}

\section{Anti-CTLA-4 Antibody "Ipilimumab" and "Tremelimumab": Checkpoint Inhibitor (Checkpoint Blocking Antibodies)}

As cytotoxic T-lymphocyte antigen-4 (CTLA- 4 ) is the T cell activation negative regulator,Anti-CTLA-4 antibody "Ipilimumab" is started to be used as target treatment in cancer immunotherapy. It shows effect by providing tumour regression by $T$ cell activation and proliferation $(34,35)$.

In Phase 1-2 study on 50 patients in which monotherapy and radiotherapy are applied together, average survival period was measured as 17.4 months, complete response from 3.6\% of the patients and partial response from $7.1 \%$ of the patients were taken and stabile disease in 21.4\% and PSA decrease over 50\% in 16\% of the patients were observed (36). Significant PSA decrease and objective clinical response were observed in phase 1 studies made by combining GM-CSF GVAX and Prostvac (37). Ipilimumab and placebo was applied (399/400) to metastasic CRPC patients who had progressed radiotherapy after docataxel chemotherapy in phase 3 study made with 799 patients and average survival was detected as 11.2 months in medicine group and 10 months in placebo group. Survival period without progression was found statistically significant when compared to the placebo branch (4/3.1 months, $p<0.001)$ (38). Common side effects were weakness, rash, itching, vomiting, constipation and weight loss and it was stated that adrenal deficiency, hepatitis and autoimmune colitis were observed when evaluated immunologically $(37,38)$. 


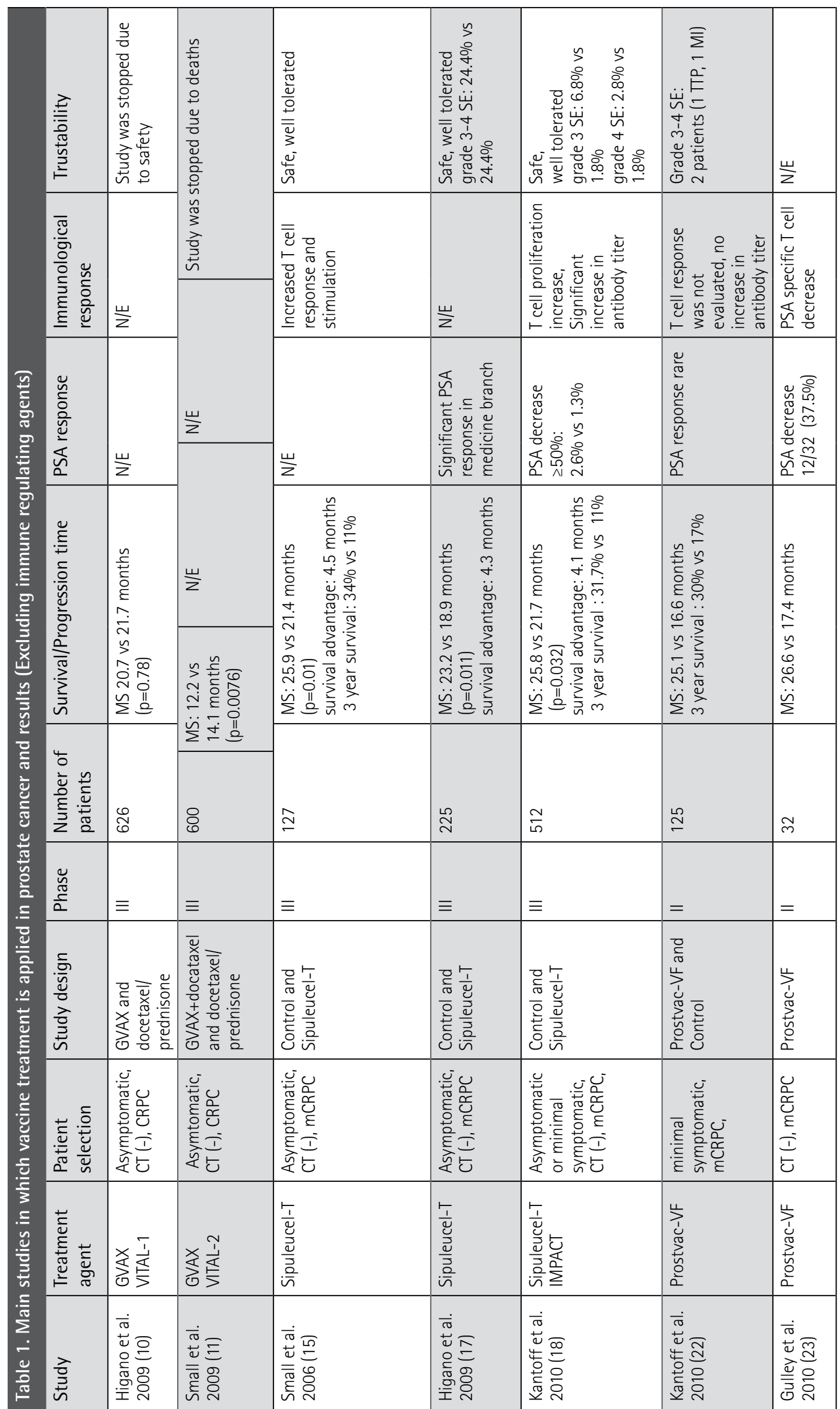




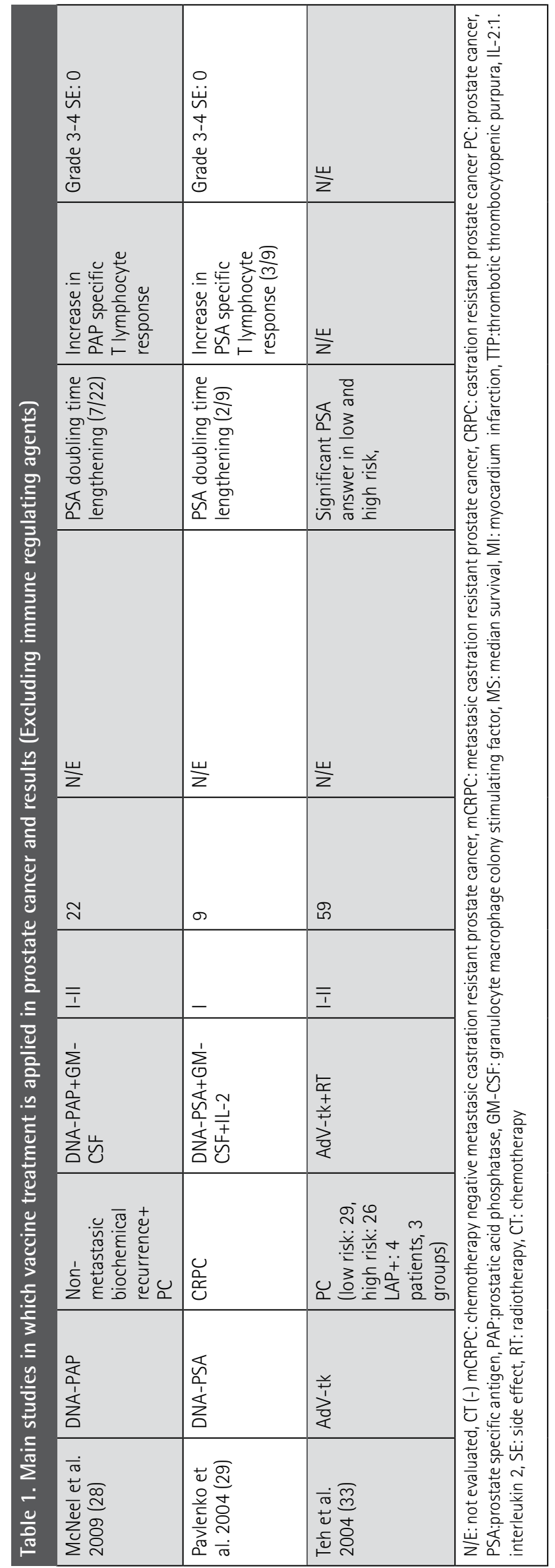

Another Anti-CTLA-4 antibody "Tremelimumab" was evaluated in phase 1 study in 11 patients with biochemical recurrence and although the safety profile was good no significant oncological data was obtained (39).

\section{Anti-PD-1 (Programmed Death)/PD-L1: Checkpoint Inhibitor (Checkpoint Blocking Antibodies)}

As they are also effective on B lymphocyte and Natural killer cells together with Anti-PD-1 T lymphocytes, they have a wider effect compared to Anti-CTLA-4 antibody. PD1 is an immune system blocking antibody. For this reason Anti-PD-1 shows antitumour effect. PD-L1 is the ligand of PD-1. Anti-PD-1 (programmed death) "Nivolumab" was given to 17 CRPC patients in phase 1 study made and no objective response related to medicine was observed in patients $(38,40)$. It was observed that PD-L1 was expressed low in CRPC patients (40). In study made using PD-1/PD-L1, it was observed that objective response was received in different cancer types. Phase 1b/2 studies (NCT01420965, NCT00730639) in prostate cancer are still continued (38).

Studies made on check point inhibitors and continuing studies are summarized in Table 3 and Table 4.

Anti-OX40, anti-Her-2/neu (MDXH210), anti-TAG (mAb CC49), antiPSMA (trastuzumab, rituximab) and similar medicines show antitumoural effect by the passive immunization provided by monoclonal antibodies (40).

\section{Result}

Together with cytoreductive treatments, vaccine treatments have an effective potential lengthening general survival, decreasing tumour load in long term and increasing cancer development $(38,41,42)$. As the results in the studies made so far are positive, combining radiotherapy, chemotherapy or new antiandrogens and immunotherapy in order to be used for metastasic CRPC patients especially and the early stage in prostate cancer will be a more commonly applied modality in the future. But other clinical data and studies to support this are still needed.

Concept: Mehmet Giray Sönmez, Cengiz Kara

Design: Mehmet Giray Sönmez, Cengiz Kara

Data Collection or Processing: Data collection or Processing wasn't done.

Analysis or Interpretation: Analysis or interpretation wasn't done.

Literature Search: The literature search was done with Pubmed.

Writing: Mehmet Giray Sönmez

Peer-review: Externally peer-reviewed.

Conflict of Interest: No conflict of interest was declared by the authors.

Financial Disclosure: The authors declared that this study has received no financial support.

\section{References}

1. Jager $D$, Jager $E$, Knuth $A$. Immune responses to tumour antigens: implications for antigen specific immunotherapy of cancer. J Clin Pathol 2001;54:669-674.

2. Sakalar C, Izgi K, Canatan H. Cancer Immunotherapy and Monoclonal Antibodies. Firat Uni Med J Health Sci 2013;27:105-110.

3. Schlom J Therapeutic cancer vaccines: current status and moving forward. J Natl Cancer Inst 2012;104:599-613. 
Table 2. Continuing studies on the prostate cancer vaccinations (except immune regulatory agents)

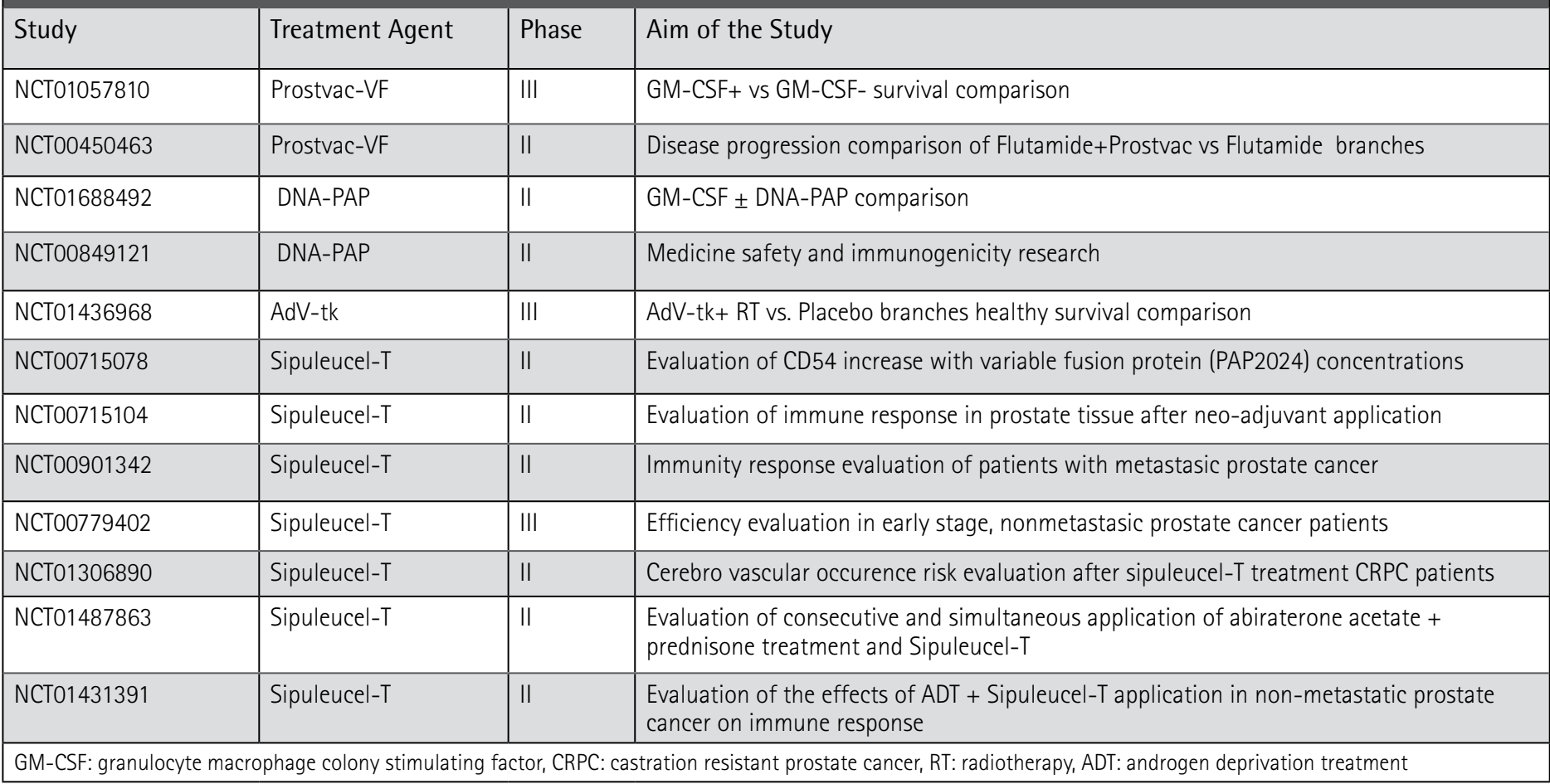

Table 3. Studies made on check point inhibitors (37)

\begin{tabular}{|c|c|c|c|c|c|c|}
\hline Study & Treatment Agent & Phase & $\begin{array}{l}\text { Number of } \\
\text { patients }\end{array}$ & $\begin{array}{l}\text { Patient } \\
\text { Population }\end{array}$ & $\begin{array}{l}\text { Average } \\
\text { survival }\end{array}$ & Results \\
\hline Small et al. 2007 & Ipilimumab & 1 & 14 & mCRPC & N/A & $\begin{array}{l}\text { Safe, } \\
\text { PSA decrease > 50\%:14.3\% }\end{array}$ \\
\hline Fong et al. 2009 & Ipilimumab + GM-CSF & 1 & 6 & mCRPC & N/A & $\begin{array}{l}\text { Safe, } \\
\text { PSA decrease >50\%:50\% } \\
\text { RECIST criteria: } \\
\text { Partial response: } 16.7 \%\end{array}$ \\
\hline Madan et al. 2012 & $\begin{array}{l}\text { Ipilimumab } \\
\text { +PROSTVAC }\end{array}$ & I & 30 & $\mathrm{mCRPC}$ & $\begin{array}{l}34.4 \\
\text { months }\end{array}$ & $\begin{array}{l}\text { Safe, } \\
\text { PSA decrease }>50 \%: 50 \%\end{array}$ \\
\hline $\begin{array}{l}\text { Van den Eertwegh et al. } \\
2012\end{array}$ & Ipilimumab+ GVAX & 1 & 16 & mCRPC & $\begin{array}{l}29.2 \\
\text { months }\end{array}$ & $\begin{array}{l}\text { Safe, } \\
\text { PSA decrease 50\%:50\% }\end{array}$ \\
\hline Slovin et al. 2013 & Ipilimumab & $|-| \mid$ & 50 & $\mathrm{mCRPC}$ & $\begin{array}{l}17.4 \\
\text { months }\end{array}$ & $\begin{array}{l}\text { Safe, } \\
\text { PSA decrease }>50 \%: 16 \% \\
\text { RECIST criteria: } 3.6 \% \text { complete, } 7.1 \% \\
\text { partial response, } 21.4 \% \text { stable disease }\end{array}$ \\
\hline Kwon et al. 2014 & Ipilimumab & III & 799 & CT- mCRPC & $\begin{array}{l}11.2 \\
\text { months }\end{array}$ & $\begin{array}{l}\text { Average survival period according to } \\
\text { placebo is statistically insignificant. } \\
\text { (11.2/10 months, } p=0.053) \text { Survival } \\
\text { period without progression is } \\
\text { statistically significant } \\
\text { (4/3.1 months, } p<0.001)\end{array}$ \\
\hline McNeel et al. 2012 & Tremelimumab & I & 11 & $\begin{array}{l}\mathrm{PC} \text { with PSA } \\
\text { recurrence after } \\
\text { local treatment }\end{array}$ & N/A & $\begin{array}{l}\text { Safe, Psa doubling time no significant } \\
\text { increase }\end{array}$ \\
\hline Topalian et al. 2012 & Nivolumab & I & 17 & CRPC & $\mathrm{N} / \mathrm{A}$ & Safe, No objective response \\
\hline
\end{tabular}

N/A: not applicable, RECIST: response evaluation criteria, CT-mCRPC: post chemotherapy metastasic castration resistant prostate cancer, mCRPC: metastasic castration resistant prostate cancer, PC: prostate cancer, PSA: prostate specific antigen, GM-CSF: granulocyte macrophage colony stimulating factor 
Table 4. Continuing studies on check point inhibitors (37)

\begin{tabular}{|l|l|l|l|l|l|l|}
\hline Study & Treatment Agent & Phase & $\begin{array}{l}\text { Number of } \\
\text { patients }\end{array}$ & Patient Population & Study branches \\
\hline NCT01057810 & Ipilimumab & III & 600 & Ending date \\
\hline NCT01530984 & Ipilimumab & II & 54 & CT-mCRPC & Ipilimumab - placebo \\
\hline NCT01688492 & Ipilimumab & I-II & 25 & CT-mCRPC & Ipilimumab - ipilimumab + \\
GM-CSF & 2018 December \\
\hline NCT01804465 & Ipilimumab & II & 66 & CT-mCRPC & Ipilimumab - Abireteron & 2015 September \\
\hline NCT01498978 & Ipilimumab & II & 30 & CT-mCRPC & Ipilimumab - Sipuleucel T & 2016 December \\
\hline $\begin{array}{l}\text { NCT01420965 } \\
\text { (Anti-PD-1) }\end{array}$ & II & 57 & mCRPC & Ipilimumab \\
\hline $\begin{array}{l}\text { CT-mCRPC: post chemotherapy metastasic castration resistant prostate cancer, mCRPC: metastasic castration resistant prostate cancer, GM-CSF: granulocyte macrophage } \\
\text { colony stimulating factor }\end{array}$
\end{tabular}

4. Geary SM, Salem AK. Prostate cancer vaccines, Update on clinical development. Oncoimmunology 2013;2:e24523.

5. Simons JW, Sacks N. Granulocytemacrophage colony-stimulating factor transduced allogeneic cancer cellular immunotherapy: the GVAX vaccine for prostate cancer. Urol Oncol 2006;24:419-424.

6. Le DT, Pardoll DM, Jaffee EM. Cellular vaccine approaches. Cancer J 2010;16:304-310.

7. Simons J, Nelson W, Nemunaitis J, Centeno A, Dula E, Urba W, et al. Phase 2 study of a GM-CSF gene-transduced prostate cancer cell line vaccine (GVAX) in hormone refractory prostate cancer. 2002 ASCO Annual Meeting, Proc Am Soc Clin Oncol 2002: 21, abstr 729.

8. Small EJ, Sacks N, Nemunaitis J, Urba WJ, Dula E, Centeno AS, Nelson WG, Ando D, Howard C, Borellini F, Nguyen M, Hege K, Simons JW. Granulocyte macrophage-colony stimulating factor-secreting allogeneic cellular immunotherapy for hormone refractory prostate cancer. Clin Cancer Res 2007;13:3883-3891.

9. Higano CS, Corman JM, Smith DC, Centeno AS, Steidle CP, Gittleman M, Simons JW, Sacks N, Aimi J, Small EJ. Phase 1/2 dose-escalation study of a GM-CSF-secreting, allogeneic, cellular immunotherapy for metastatic hormonerefractory prostate cancer. Cancer 2008;113:975-984.

10. Higano C, Saad F, Somer B, et al. A phase III trial of GVAX immunotherapy for prostate cancer versus docetaxel plus prednisone in asymptomatic, castration-resistant prostate cancer. Genitourinary Cancer Symposium; 2009.

11. Small E, Demkow $T$, Gerritsen WR et al. A phase III trial of GVAX immunotherapy for prostate cancer in combination with docetaxel versus docetaxel plus prednisone in symptomatic, castration-resistant prostate cancer. Genitourinary Cancer Symposium;2009.

12. Harzstark AL, Small EJ. Sipuleucel-T for the treatment of prostate cancer. Drugs Today (Barc) 2008;44:271-278.

13. Kantoff PW, Higano CS, Shore ND, Berger ER, Small EJ, Penson DF, Redfern $\mathrm{CH}$, Ferrari AC, Dreicer $\mathrm{R}$, Sims RB, Xu Y, Frohlich MW, Schellhammer PF; IMPACT Study Investigators. Sipuleucel-T immunotherapy for castrationresistant prostate cancer. N Engl J Med 2010;363:411-422.

14. Di Lorenzo G, Ferro M, Buonerba C. Sipuleucel-T (Provenge) for castrationresistant prostate cancer. BJU Int 2012;110:E99-104.

15. Small EJ, Schellhammer PF, Higano CS, Redfern CH, Nemunaitis JJ, Valone FH, Verjee SS, Jones LA, Hershberg RM. Placebo-controlled phase III trial of immunologic therapy with Sipuleucel-T (APC8015) in patients with metastatic, asymptomatic hormone refractory prostate cancer. J Clin Oncol 2006;24:3089-3094.
16. Kaufman HL, Wang W, Manola RS, Dipaola YJ, KO C, Sweeney T, Whiteside J, Schlom G, Wilding L, Weiner M. Phase II prime/boost vaccination using poxviruses expressing PSA in hormone dependent prostate cancer: follow-up clinical results from ECOG 7897. J Clin Oncol 2005;23 Suppl 16:4501.

17. Higano CS, Schellhammer PF, Small EJ, Burch PA, Nemunaitis J, Yuh L, Provost N, Frohlich MW. Integrated data from 2 randomized, doubleblind, placebo-controlled, phase 3 trials of active cellular immunotherapy with sipuleucel-T in advanced prostate cancer. Cancer 2009;115:36703679 .

18. Kantoff PW, Higano CS, Shore ND, Berger ER, Small EJ, Penson DF, Redfern $\mathrm{CH}$, Ferrari AC, Dreicer $\mathrm{R}$, Sims RB, Xu Y, Frohlich MW, Schellhammer PF; IMPACT Study Investigators. IMPACT Study Investigators. Sipuleucel-T immunotherapy for castration-resistant prostate cancer. N Engl J Med 2010;363:411-422.

19. Lovett R, George E, Adler A. NICE guidance on sipuleucel-T for asymptomatic or minimally symptomatic metastatic hormone-relapsed prostate cancer. Lancet Oncol 2015;16:369-370.

20. Hodge JW, Sabzevari H, Yafal AG, Gritz L, Lorenz MG, Schlom J. A Triad of costimulatory molecules synergize to amplify T-cell activation. Cancer Res 1999:59;5800-5807.

21. DiPaola RS, Plante $M$, Kaufman $H$, Petrylak DP, Israeli $R$, Lattime $E$, Manson $K$, Schuetz T. A phase I trial of pox PSA vaccines (ProstVac-VF) with B7-1, ICAM-1, and LFA-3 co-stimulatory molecules (TriComTM) in patients with prostate cancer. J Transl Med 2006;4:1.

22. Kantoff PW, Schuetz TJ, Blumenstein BA, Glode LM, Bilhartz DL, Wyand M, Manson K, Panicali DL, Laus R, Schlom J, Dahut WL, Arlen PM, Gulley JL, Godfrey WR. Overall survival analysis of a phase I randomized controlled trial of a Poxviral-based PSA-targeted immünotherapy in metastatic castration-resistant prostate cancer. J Clin Oncol 2010:28;1099-1105.

23. Gulley JL, Arlen PM, Madan RA, Tsang KY, Pazdur MP, Skarupa L, Jones JL, Poole DJ, Higgins JP, Hodge JW, Cereda V, Vergati M, Steinberg SM, Halabi $\mathrm{S}$, Jones $\mathrm{E}$, Chen $\mathrm{C}$, Parnes H, Wright JJ, Dahut WL, Schlom J. Immunologic and prognostic factors associated with overall survival employing a poxviral-based PSA vaccine in metastatic castrate-resistant prostate cancer. Cancer Immunol Immunother 2010;59:663-674.

24. Gulley JL, Madan RA, Schlom J. Impact of tumour volume on the potential efficacy of therapeutic vaccines. Curr Oncol 2011;18:e150-7.

25. Gulley JL, Madan RA, Stein WD, Wilkerson J, Dahut WL, Heery $C R$, et al. Effect of PSA-tricom, a pox-viral vaccine in prostate cancer (PCa), on tumor growth rates within 80 days after initiation in nonmetastatic PCa. Genitourinary Cancer Symposium: J Clin Oncol 2013:suppl 6:abstract \#57. 
26. Madan RA, Mohebtash $M$, Arlen PM, Vergati M, Rauckhorst $M$, Steinberg SM, Tsang KY, Poole DJ, Parnes HL, Wright JJ, Dahut WL, Schlom J, Gulley $\mathrm{JL}$. Ipilimumab and a poxviral vaccine targeting prostate-specific antigen in metastatic castration-resistant prostate cancer: a phase 1 doseescalation trial. Lancet Oncol 2012;13:501-508.

27. DiPaola RS, Chen Y, Bubley GJ, Stein MN, Hahn NM, Carducci MA, Lattime EC, Gulley JL, Arlen PM, Butterfield LH, Wilding G.A National Multicenter Phase 2 Study of Prostate-specific Antigen (PSA) Pox Virus Vaccine with Sequential Androgen Ablation Therapy in Patients with PSA Progression: ECOG 9802. Eur Urol 2014.

28. McNeel DG, Dunphy EJ, Davies JG, Frye TP, Johnson LE, Staab MJ, Horvath DL, Straus J, Alberti D, Marnocha R, Liu G, Eickhoff JC, Wilding G. Safety and immunological efficacy of a DNA vaccine encoding prostatic acid phosphatase in patients with stage DO prostate cancer. J Clin Oncol 2009;27:4047-4054.

29. Pavlenko $M$, Roos $A K$, Lundqvist $A$, Palmborg $A$, Miller $A M$, Ozenci $V$, Bergman $B$, Egevad L, Hellström $M$, Kiessling R, Masucci $G$, Wersäll $P$, Nilsson $S$, Pisa P. Phase I trial of DNA vaccination with a plasmid expressing prostate-specific antigen in patients with hormone-refractory prostate cancer. Br J Cancer 2004;91:688-694.

30. Rausch S, Schwentner C, Stenzl A, Bedke J. mRNA vaccine CV9103 and CV9104 for the treatment of prostate cancer. Hum Vaccin Immunother 2014; 10:3146-3152

31. Aguilar LK, Guzik BW, Aguilar-Cordova E. Cytotoxic immunotherapy strategies for cancer: mechanisms and clinical development. J Cell Biochem 2011;112:1969-1977.

32. Ayala G, Satoh $T$, Li R, Shalev M, Gdor $Y$, Aguilar-Cordova E, Frolov $A$, Wheeler TM, Miles BJ, Rauen K, Teh BS, Butler EB, Thompson TC, Kadmon D. Biological response determinants in HSV-tk + ganciclovir gene therapy for prostate cancer. Mol Ther 2006;13:716-728.

33. Teh BS, Ayala G, Aguilar L, Mai WY, Timme TL, Vlachaki MT, Miles B, Kadmon D, Wheeler T, Caillouet J, Davis M, Carpenter LS, Lu HH, Chiu JK, Woo SY, Thompson T, Aguilar-Cordova E, Butler EB. Phase I-II trial evaluating combined intensity-modulated radiotherapy and in situ gene therapy with or without hormonal therapy in treatment of prostate cancer-interim report on PSA response and biopsy data. Int J Radiat Oncol Biol Phys 2004;58:1520-1529.

34. Walunas TL, Lenschow DJ, Bakker CY, Linsley PS, Freeman GJ, Green JM, Thompson CB, Bluestone JA. CTLA-4 can function as a negative regulator of T cell activation. Immunity 1994;1:405-413.
35. Leach DR, Krummel MF, Allison JP. Enhancement of antitumor immunity by CTLA-4 blockade. Science 1996;271:1734-1736.

36. Kwon ED, Foster BA, Hurwitz AA, Madias C, Allison JP, Greenberg NM, Burg MB. Elimination of residual metastatic prostate cancer after surgery and adjunctive cytotoxic T lymphocyte-associated antigen 4 (CTLA-4) blockade immunotherapy. Proc Natl Acad Sci U S A 1999;96:1507415079.

37. Slovin SF, Higano CS, Hamid O, Tejwani S, Harzstark A, Alumkal J, Scher HI, Chin K, Gagnier P, McHenry MB, Beer TM. Ipilimumab alone or in combination with radiotherapy in metastatic castration-resistant prostate cancer: results from an open-label, multicenter phase I/II study. Ann Oncol 2013;24:1813-1821.

38. Carosella ED, Ploussard G LeMaoult J, Desgrandchamps F. A Systematic Review of Immunotherapy in Urologic Cancer: Evolving Roles for Targeting of CTLA-4, PD-1/PD-L1, and HLA-G. Eur Urol 2015.

39. Kwon ED, Drake CG, Scher HI, Fizazi $K$, Bossi $A$, van den Eertwegh $A J$, Krainer M, Houede N, Santos R, Mahammedi H, Ng S, Maio M, Franke FA, Sundar S, Agarwal N, Bergman AM, Ciuleanu TE, Korbenfeld E, Sengelov L, Hansen S, Logothetis C, Beer TM, McHenry MB, Gagnier P, Liu D, Gerritsen WR; CA184-043 Investigators. Ipilimumab versus placebo after radiotherapy in patients with metastatic castration-resistant prostate cancer that had progressed after docetaxel chemotherapy (CA184-043): a multicentre, randomised, double-blind, phase 3 trial. Lancet Oncol 2014;15:700-712.

40. McNeel DG, Smith HA, Eickhoff JC, Lang JM, Staab MJ, Wilding G, Liu G. Phase I trial of tremelimumab in combination with short-term androgen deprivation in patients with PSA-recurrent prostate cancer. Cancer Immunol Immunother 2012;61:1137-1147.

41. Topalian SL, Hodi FS, Brahmer JR, Gettinger SN, Smith DC, McDermott DF, Powderly JD, Carvajal RD, Sosman JA, Atkins MB, Leming PD, Spigel DR, Antonia SJ, Horn L, Drake CG, Pardoll DM, Chen L, Sharfman WH, Anders RA, Taube JM, McMiller TL, Xu H, Korman AJ, Jure-Kunkel M, Agrawal S, McDonald D, Kollia GD, Gupta A, Wigginton JM, Sznol M. Safety, activity, and immune correlates of anti-PD-1 antibody in cancer. N Engl J Med 2012;366:2443-2454.

42. Mourariev V, Mariados N, Albala D Concepcion RS, Shore ND, Sims RB, Emberton M, Pieczonka CM. The Rationale for Optimal Combination Therapy With Sipuleucel-T for Patients With Castration-resistant Prostate Cancer. Rev Urol 2014;16:122-130. 